\title{
Letter
}

\section{Corrigendum: Crusoe Glacier tongue, Axel Heiberg Island, Nunavut}

The caption accompanying the striking map of Crusoe Glacier that graced the cover of issue 242 of the Journal of Glaciology (Vol.63) requires some clarification and elaboration. The map was salvaged from McGill University's camp on Axel Heiberg Island and brought south for restoration. A copy was sent to the International Glaciological Society following a call by e-mail (14 November 2016) for cover content suggestions beyond photographs, such as satellite imagery, paintings and cartographic works. Rough notes were provided on what was deemed to be its attribution, but without specific knowledge of its history.

The published work of McGill's expedition in the early 1960s, under the leadership of Fritz Müller and the list of those who participated, has been documented by Ommanney (1987). He also contributed a comprehensive review of all Canadian glacier mapping activities to the US Geological Survey's Satellite Image Atlas (Ommanney, 2002). This remarkable series, by Richie Williams and collaborators, draws to a close later in 2018 with the publication of the final volume on Iceland.

The Crusoe map was one of the products of a collaboration between McGill University, the Photogrammetric Research Section of the National Research Council of Canada (NRC) and the Army Survey Establishment (ASE) (Müller et al. 1963). Mountaineers Eduard Leuthold and Jürg Marmet, who had accompanied Fritz Müller on the successful Swiss Mount Everest Expedition (1956), established cairns and targets for the subsequent overflight by the Royal Canadian Air Force that obtained the high-quality aerial photographs used for mapping. Ground control was completed by the surveyors, Dieter Haumann and Jörg Leisinger. In the collaboration, described by Blachut (1961, 1963), the plotting was carried out by Dieter Haumann and Don Honegger with the latter undertaking the draughting and applying the final touch of graphical representation in the Swiss style prior to printing by the ASE in two colours, black with the glacier in blue; the cover image was the base for the published map.

The Crusoe Glacier tongue map is at a scale of 1:5000 with metric contours, $5 \mathrm{~m}$ on the glacier and moraines and $10 \mathrm{~m}$ on the surrounding terrain. It was compiled from aerial photography taken on 2 August 1960, from a height of 3050 m. a.s.l. It is Map 3-3 in the map supplement of the proceedings of the glacier mapping symposium subsequently convened by the NRC (Gunning, 1966). A copy will be deposited with the World Glacier Monitoring Service (http://wgms.ch/products_fog_maps/) to complete the Expedition Fiord map collection there.

The first mass-balance measurements on Axel Heiberg Island were made on Crusoe Glacier in 1959 by Fritz Müller and Peter Adams, prior to White Glacier being selected as the focus of the long-term glaciological program there.

\section{${ }^{1} 56$ Spinney Road, Glenwood, N.S., BOW 1WO, Canada \\ ${ }^{2}$ Department of Earth Sciences, Simon Fraser University, Burnaby, B.C. V5A 156, Canada}

C. SIMON L. OMMANNEY ${ }^{1}$

E-mail: C. Simon L. Ommanney <simon.ommanney@ns. sympatico.ca>

\section{REFERENCES}

Blachut TJ (1961) Participation of the photogrammetric research section of the N.R.C. in the Jacobsen-McGill university expedition to Axel Heiberg Island in 1960. In Müller BS, ed. Preliminary report of 1959-1960. McGill University, Montréal, Que., 27-42.

Blachut TJ (1963) Photogrammetric and cartographic results of the Axel Heiberg Expedition. Can. Surv., 17, 79-80.

Gunning HC, ed (1966) Proceedings of the glacier mapping symposium. Can. J. Earth Sci., 3(6), 737-915.

Müller F and others (1963) Jacobsen-McGill Arctic Research Expedition 1959-1962; preliminary report 1961-1962 and map supplement. McGill University, Montréal, Que. (Axel Heiberg Island Research Reports).

Ommanney CSL (1987) Axel Heiberg Island bibliography and Axel Heiberg Island visitations. In Adams P, ed. Field research on Axel Heiberg Island, N.W.T., Canada: bibliographies and data reports with appendices of data from the McGill Subarctic Research Station, Schefferville. P.Q. McGill University. Centre for Northern Studies and Research, Montréal, Que., 5-55, 56-66 (McGill Sub-Arctic Research Paper 41; Axel Heiberg Island Research Reports Misc. Papers 2).

Ommanney CSL (2002) Glaciers of Canada. Mapping Canada's glaciers. US Geol. Surv. Prof. Pap. 1386-J, J83-J110. (https://pubs. usgs.gov/pp/p1386j/mapping/mapping-lores.pdf). 